\title{
Proclamation of Ferdinand VI in Cusco (23 September 1747): Art and Politics
}

\author{
Ewa Kubiak \\ (iD) https://orcid.org/0000-0002-2740-0632 \\ University of Lodz \\ Institute of Art History \\ e-mail: Ewa.kubiak@uni.lodz.pl
}

\section{Abstract}

The article analyses the royal proclamation of Ferdinand VI in Cusco (Peru) which took place on 23 September 1747, on the birthday of the king. A reconstruction of the celebration was possible thanks to two sources: the city chronicle written in the mid-eighteenth century by Diego de Esquivel y Navía and an occasional print containing a description of the ceremony by José Antonio Santander (1748). The article discusses three aspects of the presented celebrations. First of all, it presents the general context, i.e. the problem of festival celebrations related to the royal family as a part of the Spanish crown policy. Secondly, it details artistic issues related to the celebrations. It includes a description of the artistic setting with the features of occasional architecture and ephemeral painting. Finally, the article examines the local, social and political contexts of the celebrations, read as a manifestation of the city's emancipation efforts based on the emphasis of Cusco's antiquity and its rich imperial tradition in the Pre-Hispanic period.

Keywords: proclamation, Ferdinand VI, baroque festivals, Cusco, ephemeral architecture, colonial period 


\section{Introduction ${ }^{1}$}

In the seventeenth-and eighteenth-century Spanish Empire, festivals taking place in the public space belonged among the most important practices meant to confirm the power and domination of the Spanish Crown. In Idea de un príncipe politico cristiano, representada en cien empresas (1640-42) Diego Saavedra y Fajardo provides one of his political emblems, "Existimatione nixa," with an inscription containing the information that the splendour and grandeur of the court as well as all public ceremonies confirm the power of the ruler and strengthen the dignity of his majesty. A visual part of the emblem shows a column topped with a crown (Saavedro Fajardo 211; Bonet Correa 7). In the New World, the Spaniards juxtaposed the ceremonies and festivals rooted in Pre-Columbian cultures with the European model of celebration based on the humanistic ideas stemming from the Italian Renaissance (Mínguez, Rodríguez Moya, González Tornel, Chiva Beltrán 23). As Celsa Carmen García Valdés writes: "also in the New World, festivals contributed to the process of preserving power and constituted an appropriate mechanism allowing for representation and dominance of the colonial order in the public sphere and for exercising control over the [colonial community]" (García Valdés 253). ${ }^{2}$

Whether secular or religious, public festivals in Spain have for years aroused the interest of researchers; celebrations of the royal family occupy an important place among the discussed topics. Some studies offer a vast panorama of celebrations, while others are devoted to individual festivals held in specific places. Víctor Mínguez et al. discuss festivals in the public space during the Baroque period in the Spanish Viceroyalties: New Spain and the Viceroyalty of Peru. In Peru, the place, where the majority of celebrations discussed in the monograph and related to the Spanish Crown took place, was Lima, which corresponds to the intensity of festivals celebrated in the capital of the viceroyalty; the authors also mention celebrations in Quito, Santiago de Chile and Valparaiso. The researchers focus their attention mainly on royal funerary ceremonies but also mention proclamation celebrations of chosen rulers (Mínguez, Rodríguez Moya, González Tornel, Chiva Beltrán). Another work that concentrates on Spanish Baroque festivals is a book by Rafael Ramos Sosa's dedicated to celebrations in the public space in Lima in the sixteenth and seventeenth centuries. It discusses in one of the sub-chapter the festive proclamation of successive rulers of Spain: Philip II, III and IV, and Charles II and characterises the artistic setting of these festivals (Ramos Sosa 73-88). The issue is also mentioned by

1 The extended Polish version of the article was published in the Roczniki Humanistyczne in 2020.

2 "también en el Nuevo Mundo la fiesta intervino en la preservación del poder y se constituyó en un mecanismo apropiado para representar e imponer el orden colonial en la esfera pública, a la par de ejercer el control sobre los sujetos", translation mine. 
Karine Périssat, who deals with celebration of royal festivals in colonial Lima and devotes one of the sub-chapters to solemn acts of proclamation (Périssat 6o-62).

Unlike other towns of the viceroyalty, colonial Cusco has been discussed in few studies containing information about festivals associated with the royal family. In her book, Graciela Viñuales devotes a short passage to funerary ceremonies of Charles V, Charles II and Philip II, and the proclamation of Ferdinand VI based on the account of the eighteenth-century chronicler Diego de Esquivel y Navi (Viñuales 44-45, 50; Esquivel y Navia 403-405). It is also worth mentioning the article by Maria Luisa Dominguez-Guerrero on the proclamation of Philip II in Cusco (2015: 605-29) and the work of José R. Jouve Martín (219-235) containing a comparative analysis of the funerary ceremonies of Philip V and the proclamation of Ferdinand VI which took place at the same time in Lima and Cusco, as well as the article about the Lima and Cusco royal funerary ceremonies in the Bourbon era, written by Carmen Ruiz de Pardo (67-68).

\section{Royal proclamations of the Spanish Crown: global and colonial contexts}

Towns of the viceroyalties organised festivals related to key events happening in the royal family. Some celebrations commemorated the death of the ruler, his spouse or their offspring (funerary ceremonies), others - proclamations of the new king and the birth of the royal family children as well as the marriage of the rulers. All these celebrations were held in the form of public festivals and perceived as a manifestation of power of the Spanish Crown throughout Hispanic America, underlining the symbolic presence of the king in all corners of the empire.

At this point, the concept of the "king's two bodies" outlined by Ernst Kantorowicz is worth recalling. Read as a part of the generally accepted English tradition established in the Middle Ages, the notion of the king's two bodies means that the first, the "body natural", is material and mortal, like that of every human being. The other, called the "body politic", cannot be seen or touched and has a symbolic meaning; it consists of politics and government, is used to exercise power over the people and is characterised by timelessness and perfection (Kantorowicz 41-43). Thanks to its symbolic character, the second body can be multiplied, and its presence can be manifested in various places simultaneously through portraits or memorial monuments (Mínguez, Los reyes distantes; Kubiak, La pintura de batalla, 90; see also: Mínguez, Los dos cuerpos, 68-91). The two bodies of the king form an inseparable, but also invisible unity, 
always containing one in the other. Whereby, there is no doubt about the superiority of the "body politic" over the "body natural" (Kantorowicz 43). This tradition, extensive in the Middle Ages, is rooted in the customs of the ancient Roman Empire, when images of the emperor (portraits, statues, busts) were sent to all the provinces, all the cities of the whole empire, where they were worshipped in a way similar to the cult of the ruler (Kolb 41). The phenomenon of the symbolic understanding of the ruler's presence during moments crucial for the history of the kingdom also affected the manner of holding ceremonies associated with the royal family during the Renaissance and the Baroque. It was particularly important in the case of the colonial powers. In the vast majority of the Spanish Empire, the presence of the ruler had only a symbolic and political character.

The festive proclamation of the new ruler was crucial for every European monarchy. In Castile, it was celebrated at least from the fifteenth century on, and the preparations consumed significant resources. On the one hand, they were supposed to be a manifestation of loyalty to the authorities, and on the other, the grandeur of the ceremony was to underline the status of the centre, where the celebration was prepared (Domínguez-Guerrero 607). Celebrating the death of one ruler and the assumption of power by the heir were of much significance in the Spanish colonies. In areas remote from the Iberian Peninsula, from where the king was permanently absent, these festivals were the moments of cyclical power legitimisation. In this way, the celebrations not only gave the inhabitants of the colonies the chance to express their reverence, devotion and loyalty to the ruler, but also emphasised cultural cohesion of the whole empire and strengthened the sense of belonging for the inhabitants of viceroyalties distant from the Spanish Crown (Rípodas Ardanaz 245).

In the colonies, the most glamorous festivals were celebrated in the viceroyalty capitals (Mexico, Lima, or, after 1737, Bogota), but we also know accounts describing festivals related to events and changes in the royal family which were celebrated in smaller towns, usually in the audience capitals, such as Quito, Santiago de Chile and Arequipa. It turns out, however, that also Cusco was the place of numerous celebrations commemorating funerals of the king or other members of the royal family; the birth of heirs, or the proclamations of the newly anointed kings. The organisation of these festivals was a pretext to emphasise the imperial tradition of the Pre-Hispanic city and an attempt to regain its former prestige.

The preparation of a funerary ceremony was bound with the erection of a magnificent catafalque, abundant in symbols, and most often located in the cathedral. During the proclamation, an ephemeral structure was built on the main square with decorations expressing an extensive iconographic program. The presented ideological themes were usually associated with 
the content of the diseased's catafalque, but at the same time emphasised qualities and potency of the next king. The structure was where the act of proclamation took place to the sounds of bells and volleys. A preserved printed account describes the festivities, the texts of delivered sermons and descriptions of erected decorations accompanying the ceremony (Rípodas Ardanaz 245).

Funerary ceremonies and proclamations were meant to inspire a sense of renewal. Initially, during the funeral, participants were immersed in grief after the death of one ruler and then manifested their joy about the accession of the next king. In both cases, the celebrations took place both in the public space of the city and in the cathedral (or the main city temple). The funeral corteges of the deceased king and the processions manifesting support for the new one, were attended by the whole community. Among the participants, there were municipal decision-makers, all persons performing administrative and clerical functions, clergy, nobility, religious confraternities and professional guilds, as well as members of religious orders and representatives of parish communities.

\section{Proclamation of Ferdinand VI Festive celebrations and artistic setting}

Ferdinand VI was the third Spanish ruler from the Bourbon dynasty; he ascended the throne after the death of long-reigning Philip V who passed away on 9 July $1746 .^{3}$ The celebrations connected with king's death and appointment of the new ruler were prolonged in time. The information about the death of the first ruler from the Bourbon dynasty and the succession of Ferdinand VI, reached Cusco in mid-March and was publicly announced on Tuesday, 21 March 1747 (Esquivel y Navia 382-384). The first festival held in Cusco and related to the new ruler was the Day of St. Ferdinand, his patron saint. A solemn mass celebrated in the cathedral was attended by city authorities and the whole community, who, after the liturgy, sang the "Te Deum Laudamus" anthem (Esquivel y Navia 393). The next stage of the festivities related to the shift of power was the funerary ceremony commemorating the death of Philip V which was celebrated in Cusco on 17 July 1747. The celebrations took place both in the urban space and in the cathedral, where a sumptuous catafalque was erected to commemorate the ruler (Esquivel y Navia 396-399). Then, on 12 August it was

3 Philip $\vee$ was the first king on the Spanish throne representing the Bourbon dynasty. His reign lasted for almost 46 years from 1700 until his death in 1746, with a small break in 1724, when he abdicated in favour of his son Luis I, but due to the imminent death of the firstborn in August of the same year, Philip returned to the Spanish throne. As Henry Kemen wrote, even in the title of his book, he was "the king who ruled twice" (Kemen 2000). 
announced that the swearing and proclamation ceremony of the new king, Ferdinand VI, would take place on his birthday, that is, on 23 October of the same year. All Cusco residents were obliged to participate in the celebrations on pain of a fine (Esquivel y Navia 40o). Before the proclamation ceremony of Ferdinand VI, another funerary ceremony dedicated to Philippe V was held at the churches of the Franciscans (18 October) and the Mercedarians as well as the hospital church of San Juan de Dios (19 October) and at the Jesuit church (20 October). Meanwhile, wooden structures were already being prepared on the three most important city squares to celebrate the upcoming proclamation festival. We can describe and analyse the course of celebrations connected with the assumption of the Spanish crown by Ferdinand VI thanks to two sources. The first one is the well-known and already mentioned, eighteenth-century description detailed in the account of the Cuscan chronicler Diego de Esquivel y Navi which has already been used by other authors writing on the subject. The other one, so far rarely quoted, is the book of the funerary ceremonies of Philip V and the proclamation of Ferdinand VI prepared by Antonio Santander and published in Lima. The author describes in detail the funerary ceremonies: their social, political and artistic aspects; then in the second part of the publication moves on to describe the festive proclamation of the successor to the Spanish throne, the new King Ferdinand VI [Il. 1].

Already on 22 October, on the eve of the proclamation ceremony, the city streets were prepared, and the townspeople were obliged to hang decorative fabrics in the windows facing the cortege route. The bells were rung in all churches, and fireworks were fired at Regocijo Square at night (Esquivel y Navia 403). "Five artificial castles were erected in the corners of the main square and in the centre" los cinco artificiosos Castillos, colocados en las quarto esquinas, y centro de la plaza" (Santander; translation mine) to make fireworks look more effective. On 23 October, the festivities began with a mass held in the cathedral, and attended by the city council, officials, judges, military, clergy and other members of the Cusco community. Just like in Europe, celebrations in Latin America were accompanied by occasional architecture; triumphal arches and magnificent structures were erected in the streets and squares with representations constituting the iconographic program matching the celebrated event. During the proclamation, erected platforms towered above the squares, presented as the place of triumph of the new ruler. During the ceremony dedicated to Ferdinand VI, three such structures were built in Cusco: on the cathedral stairs at the main square; at the Recocijo square next to the Cabildo building (the seat of the City Council) and on the square next to the church of San Francisco, at the entrance belonging to the cemetery of the order. They were all carpeted and decorated, but only one, placed near the City Council seat, depicted the portrait of the ruler. There were also "eight arches richly decorated 
like during the Corpus Christi procession / ocho arcos trinfales ricamente edornados como en la fiesta de Corpus Christi" and a few smaller ones (Esquivel y Navia, 403; Santander writes about 9 arches; translation mine). We may have an idea of what triumphal arches might have looked like thanks to the canvases of a painting series depicting the Corpus Christi procession [Il. 2]. This is a series painted in 1677-1780 (Mariátegui Oliva 21-23; Mesa, Gisbert 160-80; Dean 61-63, 86) and used as a decoration of Santa Ana church in Cusco. The paintings remained there until 1968 and were then moved to the Museum of Religious Art (Museo de Arte Religioso) in Cusco, which nowadays exhibits 12 canvases. The paintings show procession groups of the Cuscan community; we can accordingly see representatives of parishes, religious confraternities and orders. There were also attempts to show the urban space with its decorations, including triumphal arches. These are single-pass structures, topped with sculptural groups, decorated with painting representations and placed on archivolt supports. Although the iconographic sources come from the end of the seventeenth century, and the proclamation of Ferdinand VI took place in the middle of the next century, we can assume with great probability that the structures were similar due to the repetition of patterns and longevity of the tradition deeply rooted in the Cuscan region. Another source of information about the forms of arches were contracts between founders and artists. We may refer to an exemplary description of structures that was to be erected for Corpus Christi in 1702. The guild of cotton manufacturers, silk manufacturers and haberdashers commissioned the construction of an arch "according to the drawing, with twisted Solomonic columns on four bases and very beautifully decorated /[...] conforme el dibujo que tiene con las columnas salomónicas torcidas de quatro pies y muy bien adornado" (Cornejo Bouroncle 257; ARC, Sección Notarial, Francisco Maldonado (207), f. 176 r).

The act of proclamation began on a platform erected in front of Cabildo. Corregidor $^{4}$ of Cusco picked up the royal pennant and Real Cédula. He kissed the document, unrolled it and started the act of swearing-in of the city to the power of the new King Ferdinand VI. The same procedure took place on the three squares. Then the platforms and most of the triumphal arches were pulled down to make space for the march of Cusco residents the next day. In the evening, there were corteges of the representatives of all eight town parishes, attended by Indians in Inca costumes. At the end, there was a triumphal chariot with portraits of the king and queen surrounded by musicians playing harps, guitars, violins

4 Corregidor is a clerical function, characteristic of Spain and its colonies, which was introduced in Peru in 1560. The person nominated for this position exercised administrative and judiciary power in the city or the whole region on behalf of the king, and in the colonial realities was also responsible for mitigation indigenous peoples exploitation (Roel Pineda 89-94; Hidalgo Nuchera 454-456; Pietraszczyk-Sękowska 45). 
and bandolas (a four-stringed little musical instrument characteristic of Latin America). The described cortege was attended by " 97 Incas, 27 noblemen and the rest" (Esquivel y Navia 404-405). They were all very richly dressed. Creoles, often riding on horseback, were accompanied by slaves, referred to as negros or esclavos (Santander). The Indians, on the other hand, had very diverse outfits. Extra splendour was added by people dressed up as "the fiercest and strangest/ fate of mas ferozes y estraños" animals, which made it possible to compare the main square in Cusco with the arenas of ancient Rome filled with wild beasts (Santander). There was also a group of Indians dressed in Inca costumes, with a maskapaycha as a symbol of royal power [Il. 3]. Representatives of each parish carried emblems that were briefly described by Santander. No drawings of plates have been preserved, but referring to well-known emblem books, we can try to describe some of them.

Emblematic art, popular in the Old World at the time, quickly found its way from Europe to the Spanish colonies in America. Intellectual rebuses, ambiguous rhyming songs and enigmatic lemma were in fashion. The rapid assimilation and dissemination of European patterns in remote areas were possible thanks to the transatlantic flow of goods, especially books and graphics. However, in the American viceroyalties, the imported patterns were, first of all, reinterpreted and transformed by adding their own contexts and creating local iconographic programs. The same motifs were repeated but given new meanings. America developed a separate artistic language of the Baroque era, consisting of a syncretism of European trends in contact with the local reality (Mínguez et al. 105). In the Andean regions of the Viceroyalty of Peru, not only painting, but also emblematics gained a unique quality, subject to the process of cultural metissage (more on "cultural metissage" see: Gruzinski; Laplantine, Nouss; Kubiak, Cultural metissage 147-166). Among popular books, stored in many monastic and private libraries, there are the Emblemat Libellus by Andrea Alciati or Emblemas morales Sebastiano de Covarrubias y Orozco (in the Jesuit libraries see Kubiak, Reinterpretacje 343).

At the front, there was a plate carried by the faithful of the Santiago parish and depicting the coat of arms of Spain with a golden inscription "Viva España." It could have been the coat of arms of Castile and Leon, very often functioning in Cusco as the coat of arms of Spain, which can be seen on the coats of arms placed on the city buildings [Il. 4]. It could also have been a full royal coat of arms, like the one presented during the funerary ceremony of Louis I in the cathedral in Mexico [Il. 5]. Representatives of the Hospital de los Naturales parish carried a plate showing a crown placed on a cushion with an inscription "Viva el Rey." We can find such an emblem in the books by Diego de Saavedra Fajardo (1642: 127) and Juan de Borja (1680: 371) [Il. 6]. In both cases, these were emblems referring to royal power. Parishioners from San Jerónimo 
carried a plate with a crossed sceptre and a sword and an inscription "Viva Don Fernando VI", while the faithful from Santa Ana church - a plate with a split pomegranate with grapes visible inside, probably similar to the emblem "Et dulciter acre temperabis" from the book by Jun de Borja (1680: 403) [Il. 7] or Antonio de Lorea (1674), with an inscription "Viva la Reyna." A plate of Belén parish representatives depicted a cloud-spreading dew with an inscription "Viva Maria Barbara." The faithful from San Blas parish carried an emblem showing two mountains: a golden one and a silver one with an inscription "Viva el Cuzco." Symbolic representation of two mountains, one of them being a volcano, is known from books and other emblematic performances [No. 8]. In this case, however, it emphasised specificity of Cusco and location on the trade route between the coast and the Andean areas abundant in ore. Next in line were San Sebastián parish representatives with the image of the crowned globe and an inscription "Por Fernando." Finally, at the end, parishioners from San Cristobal church carried a plate presenting two columns with an inscription "Non plus." The latter representation, originally associated with Charles V, is known in many different variants [Ils. 9-10] (Bernat Vistarini, Cull 223-25; Vignolo 139-64). As we can see, the vast majority of emblems concerned royal authority, the king himself and members of the royal family, but some representations had local features.

\section{Proclamation of Ferdinand VI Local context}

The funerary ceremony of Philip V and the proclamation of Ferdinand VI were organised at the same time in Cusco and in Lima, and in both cases the festivities were related to the manifestation of the position of both cities. It was the time when the capital of the Viceroyalty of Peru was regaining strength after the devastating earthquake from 28 October 1746 (Pérez-Mallaín Bueno), and the Cuscan authorities, as José R. Jouve Martín pointed out, decided to try to restore a stronger position of the Andean city, referring to its Pre-Hispanic traditions and its former capital functions in the Inca empire (Jouve Martín).

In Lima, the ideological program of celebrations associated with the death of the king and the coronation of his heir was focused on the theme of the Phoenix. In this case, the mythological bird has a double meaning. On the one hand, it refers to one of the iconographic traditions of metaphorical presentation of the Spanish ruler, and on the other, it symbolises the situation of the city, which was completely destroyed, but, like the mythical Phoenix, was soon to be reborn from the ashes (Jouve Martín). 
In Cusco, the most important motif repeating in the iconographic programs decorating the occasional constructions erected during the funerary ceremony of Philip V and the proclamation of Ferdinand VI was the Sun. Of course, we can refer again to the European and Spanish traditions which identified the king with the solar emblems. In the book Los Reyes Solares, Víctor Mínguez shows the origins and popularity of the motif in the context of the symbolic representation of the Spanish rulers. He points to its intensified presence during the festivals associated with the Spanish Crown in the American colonies (Mínguez, Los reyes solares 211-245). However, in this case, as Jouve Martín notes, the iconography can also be interpreted in the local context. The Sun was not only a symbol of Spanish kings, but also of Cusco itself. It referred to its Inca tradition and the major deity of the Incas, Inti; therefore, it is not only the Sun-ruler, but also the "the ancient Sun/ el Sol antiguo" (Santander 1748) of the Pre-Hispanic empire (Jouve Martín 229). Describing the festivals organised after the death of Philip V and in connection with the proclamation of Ferdinand VI, José Antonio Santander repeatedly refers to the theme of the Sun, usually in connection with the former city splendour, comparing it to the ancient Roman cities. Karine Périssat emphasises that the place closest to the Spanish Crown, where the viceroyalt court functioned was Lima. However, it was also a city with its own history, politics, economy and, finally, its Creole society, which to some extent identified itself with the Spanish Crown, but primarily emphasised its sense of belonging to the Viceroyalty of Peru (Périssat 193-195). Cuscan ambitions were similar, but its history, politics, economy and society were different. The sources of Cusco's strength and the attempt to change its position in Peru were sought in the old Inca tradition of the city, when it functioned as the capital of the empire. The Cuscan society was dominated by mestizos and Indians, in the presence of a locally rooted Creole group. It was this group that was perceived as the source of strength and grandeur of the city, which was to reflect the social structure of all Peru, and focus its needs and desires, like in the lens. 
Illustration Descriptions

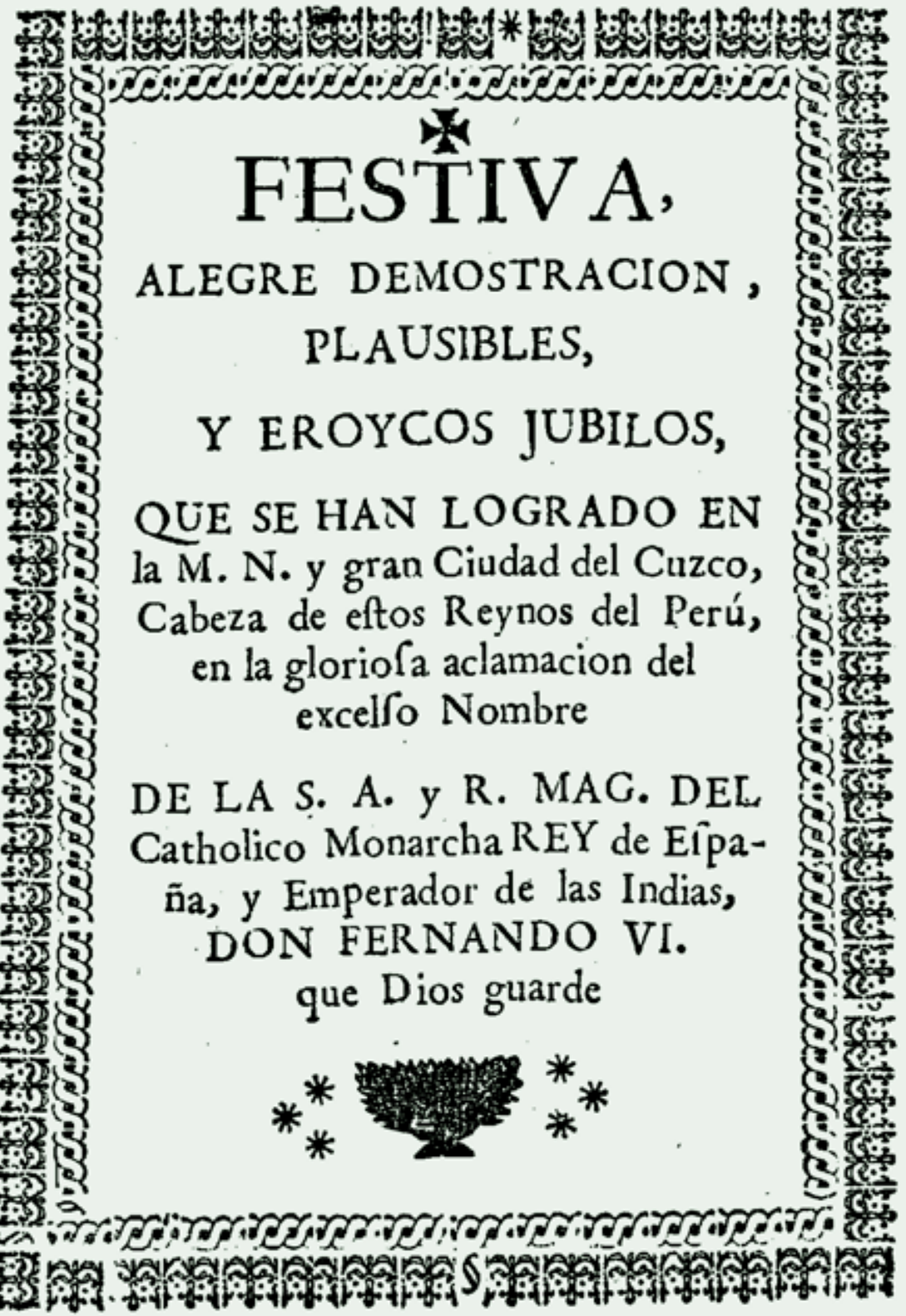

Illustration 1. The title page of the book published in Lima on the occasion of the proclamation of Ferdinand VI in Cusco; (Santander 1748). 

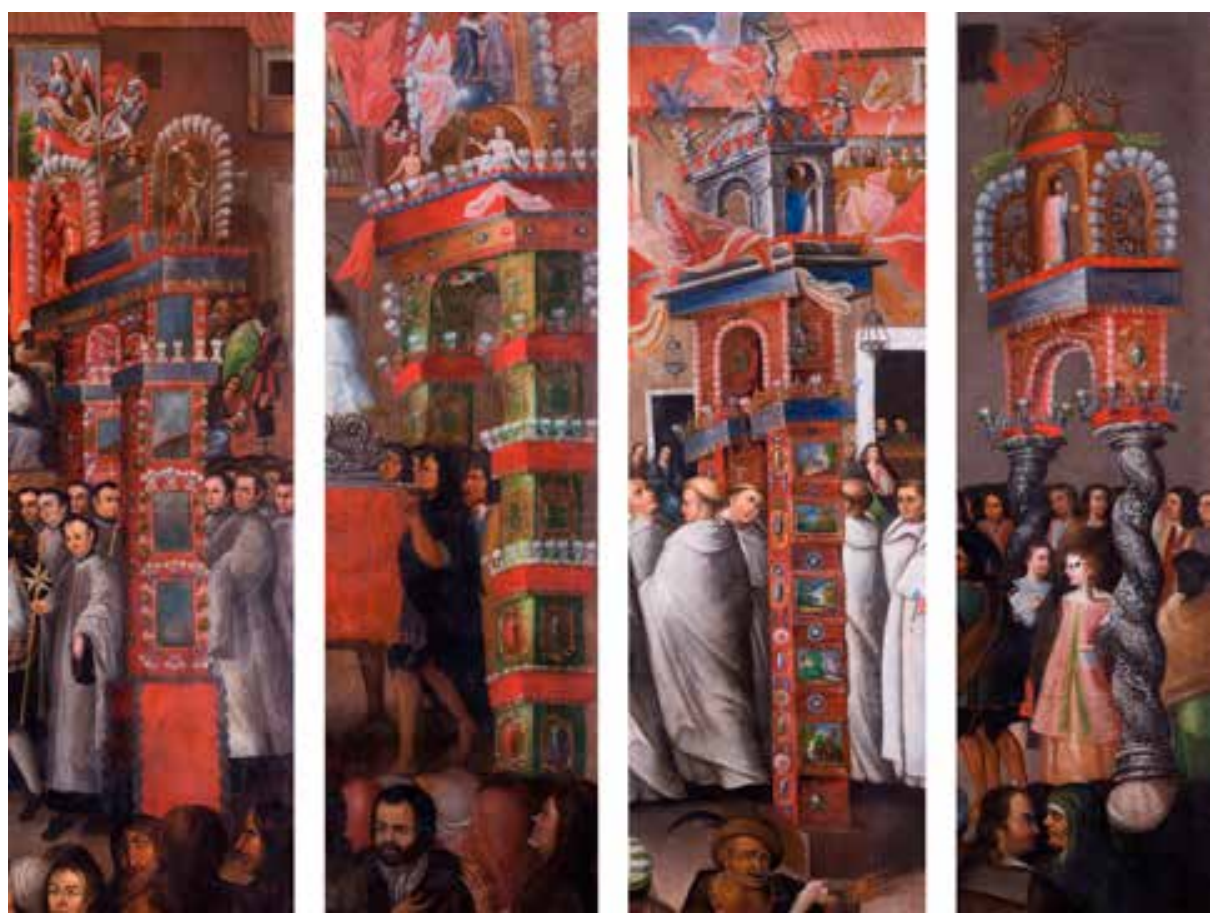

Illustration 2. Fragments of paintings from the Corpus Christi series showing triumphal arches.

In the sequence: Procession with representation of corregidor Alons Pérez de Gúzman; Procession of contraternity of St. Rose of Lima and Immaculately Conceived Virgin Mary (La Linda); procession of the Order of the Mercedarians; procession of the confraternity of St. John the Baptist and St. Peter; about 1675-1680, oil on canvas, Museo de Arte Religioso, Cusco, Peru [photo E. Kubiak 2018]. 
Proclamation of Ferdinand VI in Cusco...

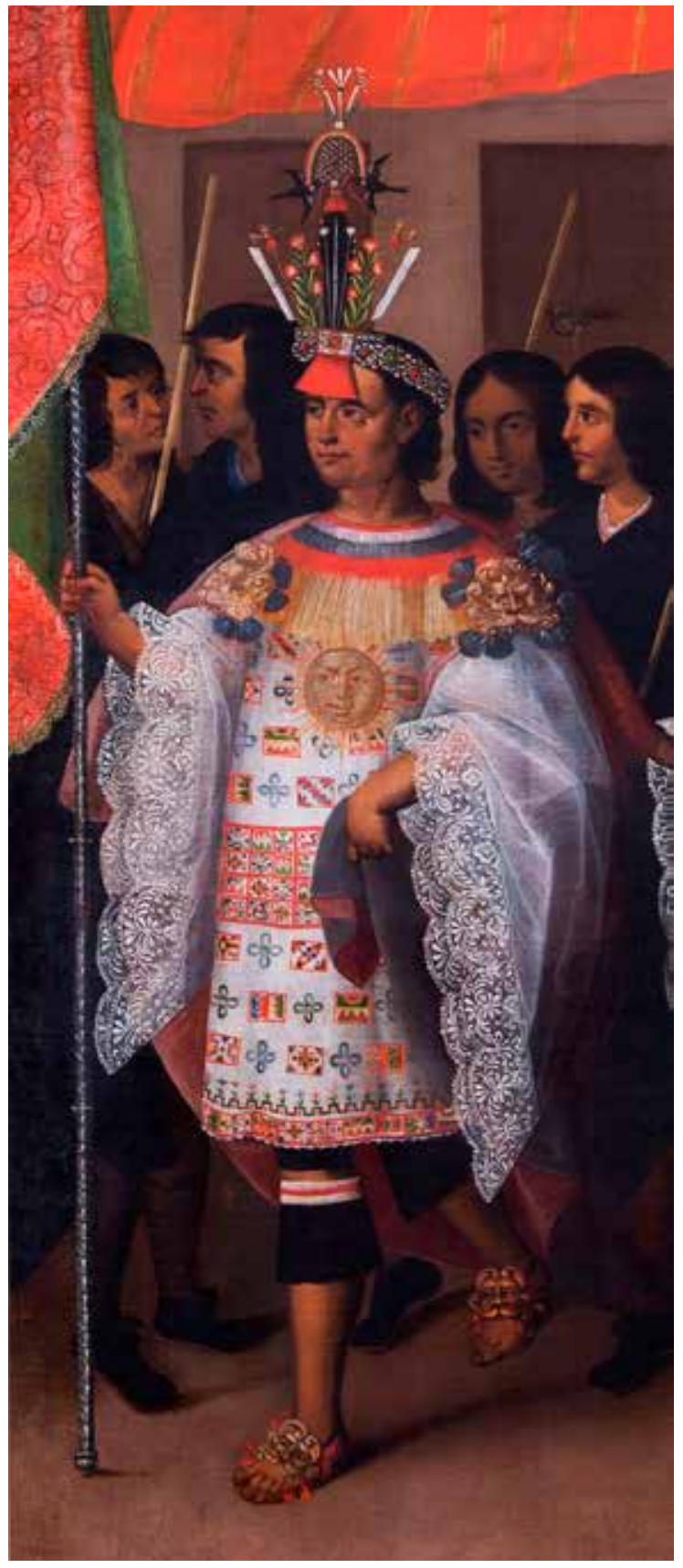

Illustration 3. Indian cacique dressed in traditional Inca outfit with elements of Spanish clothing, a fragment of the painting showing the procession of San Sebastián parish in Cusco; about 16751680, oil on canvas, Museo de Arte Religioso, Cusco, Peru [photo E. Kubiak 2018]. 

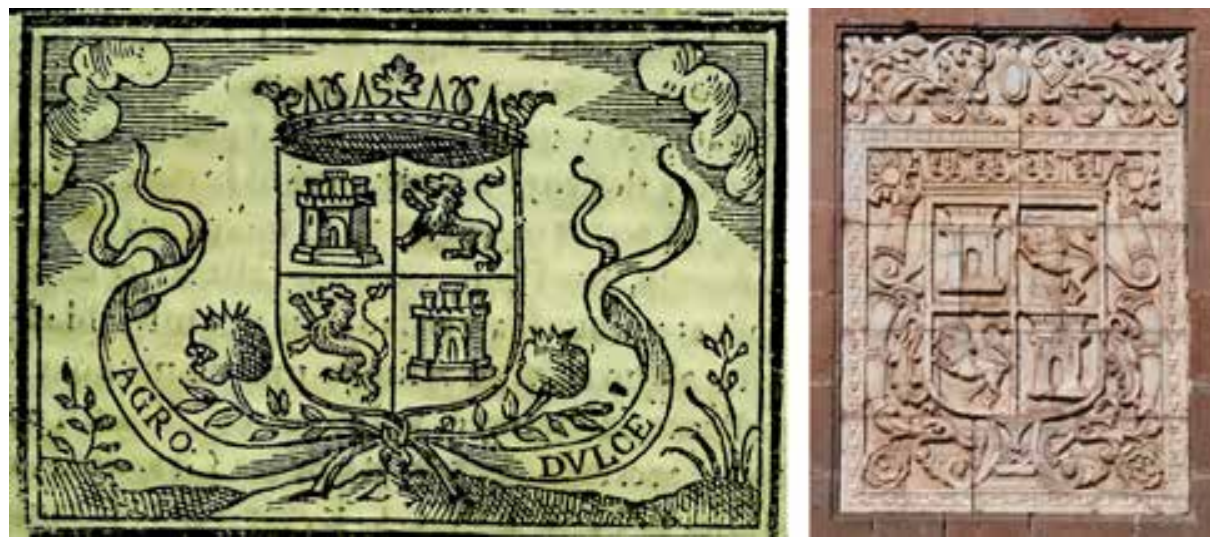

Illustration 4. The royal coat of arms, the emblem of XXX "Agro Dulce", (Horrozco y Covarrubias 1604: 160); The coat of arms of Castile and Leon, functioning as a simplified coat of arms of the King of Spain, the façade of the El Triunfo church, Cusco, Peru [photo E. Kubiak 2018]. 


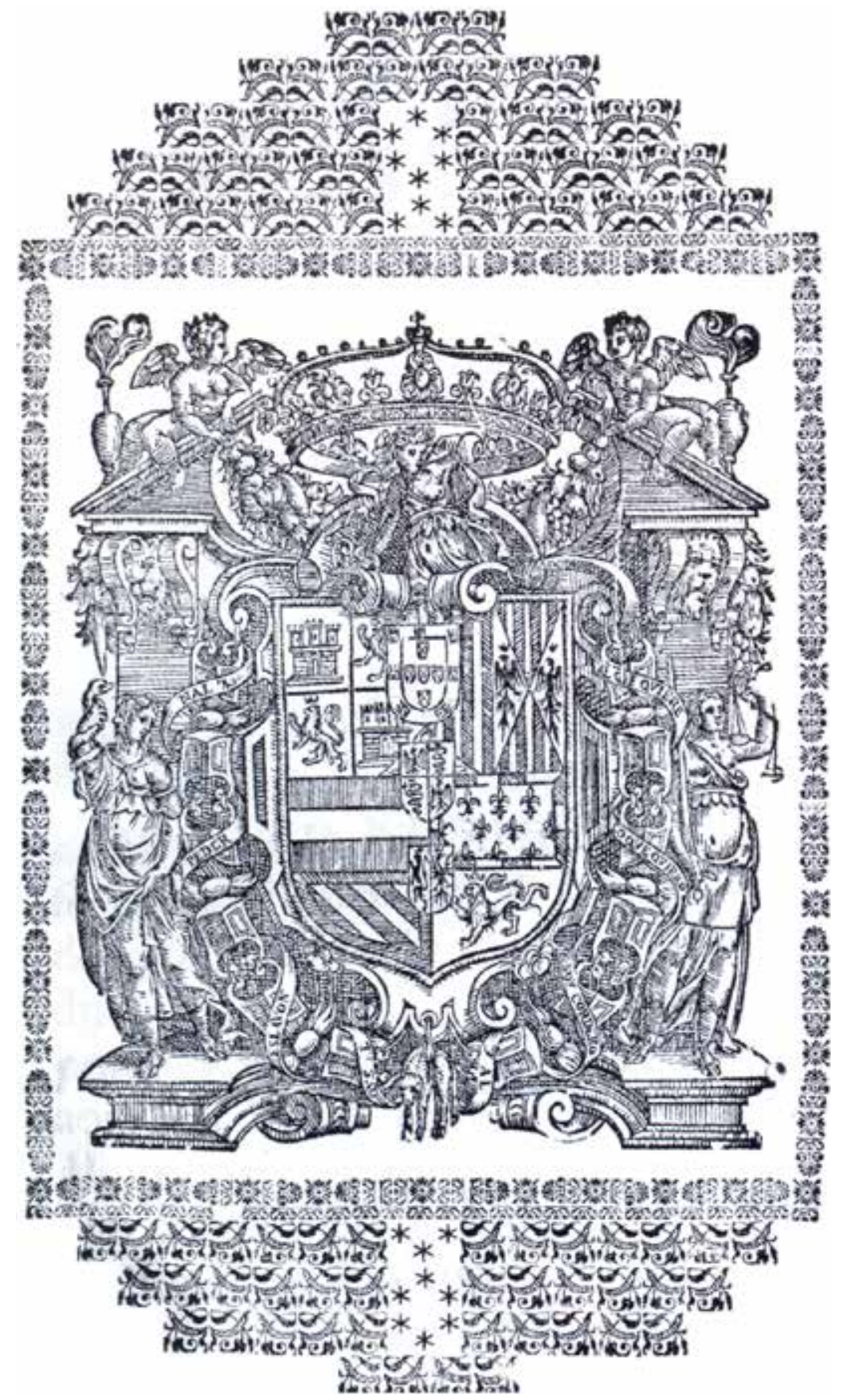

Illustration 5. The royal Coat of Arms, Book of funerary ceremony of Louis I in the Cathedral of Mexico, (Villerias Roelas 1725). 

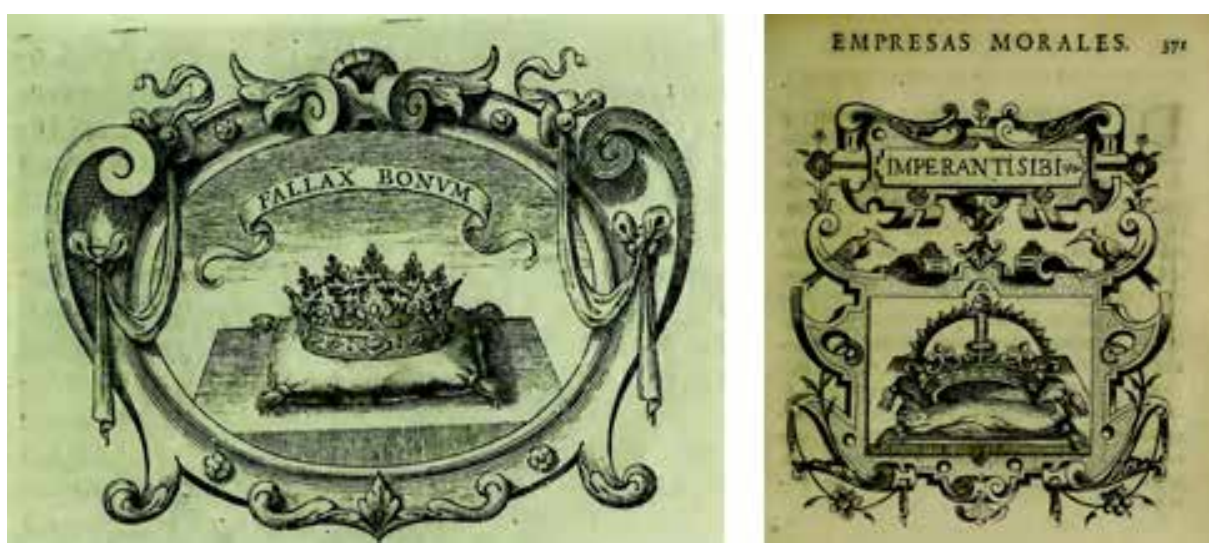

Illustration 6. The emblem "Fallax Bonum" (Saavedra Fajardo, 1640-1642: 127); The emblem "Imperantisibi" (Borja 1680: 371)

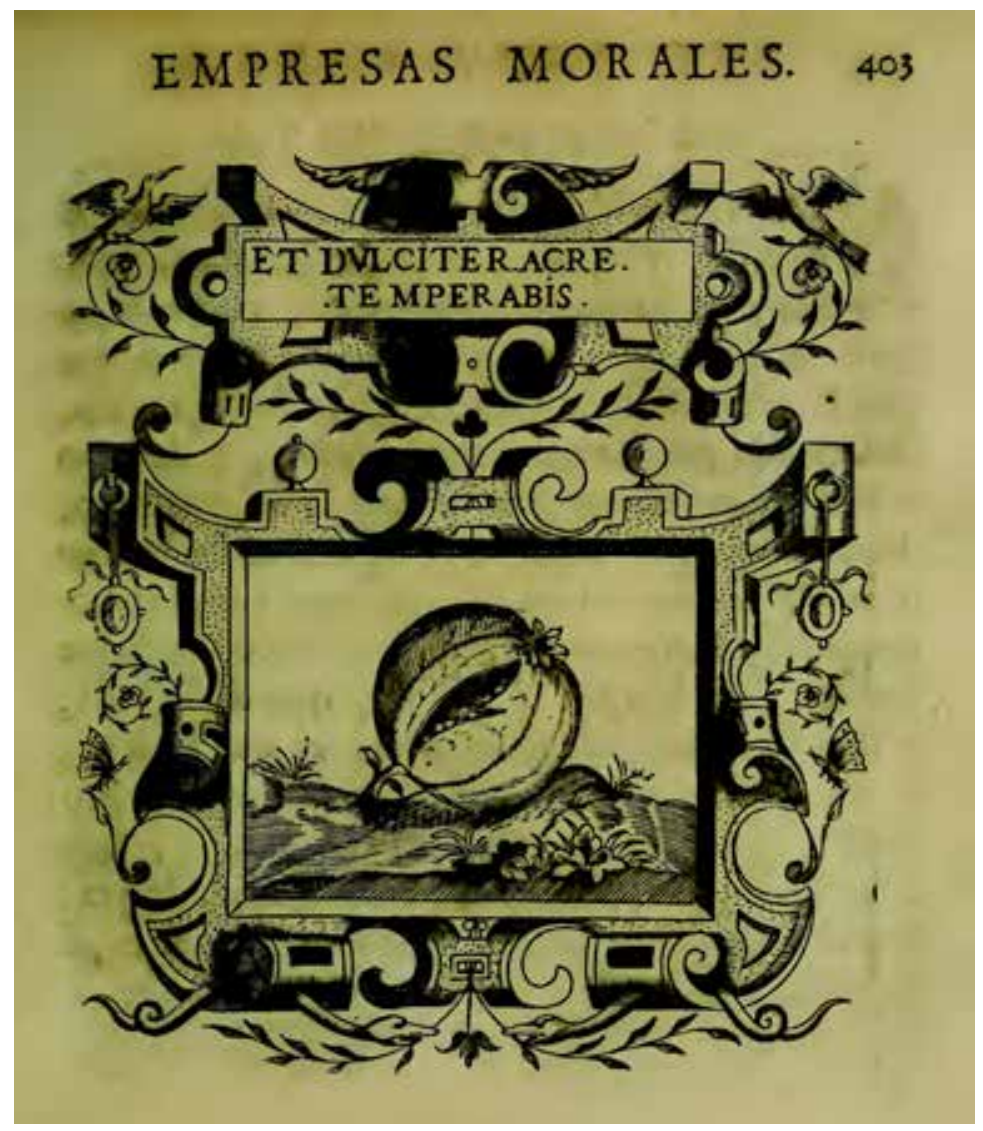

Illustration 7. The emblem "Et dulciter acre temperabis" (Borja 1680: 403). 
Proclamation of Ferdinand VI in Cusco...
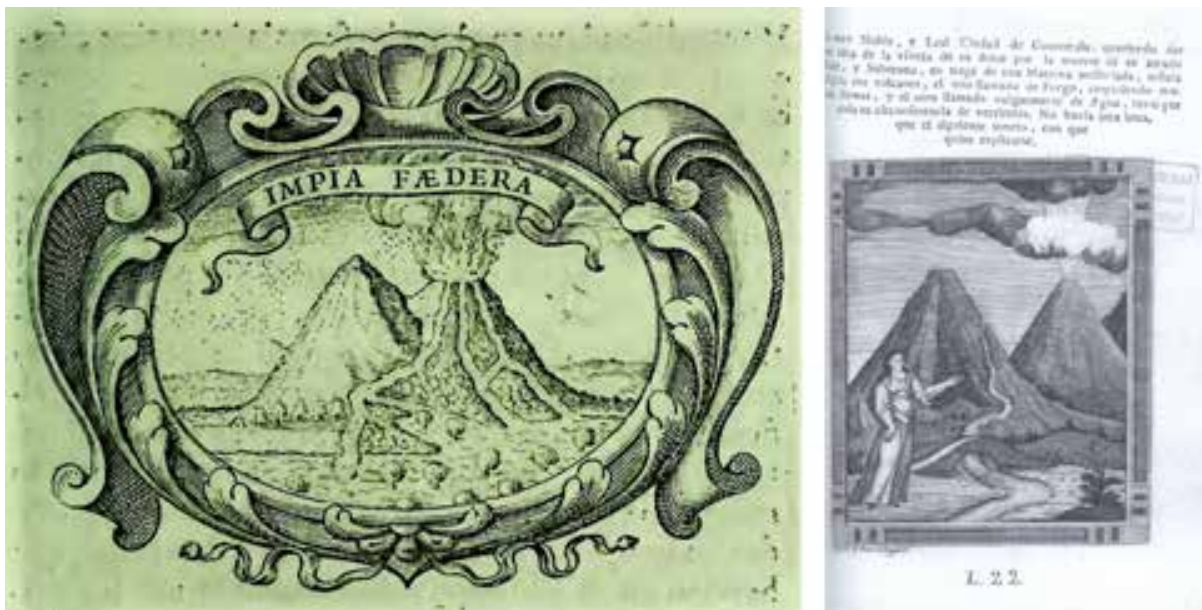

Illustration 8. The emblem „Impia Faedera” (Saavedra Fajardo 1642: 681); One of hieroglyphics from the royal books of Charles III in the city of Guatemala, plate 22, (Cadena 1789).

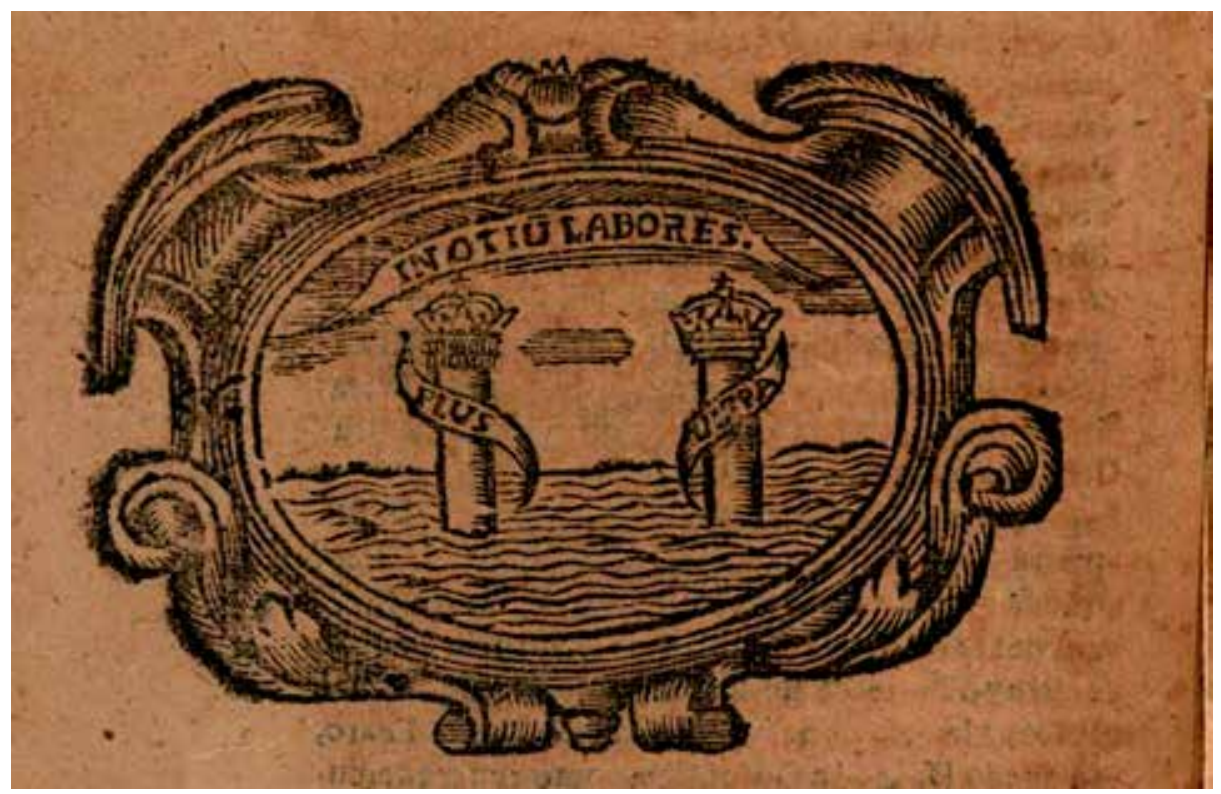

Illustration 9. The emblem "Non plus ultra" (Lorea 1647: 8). 


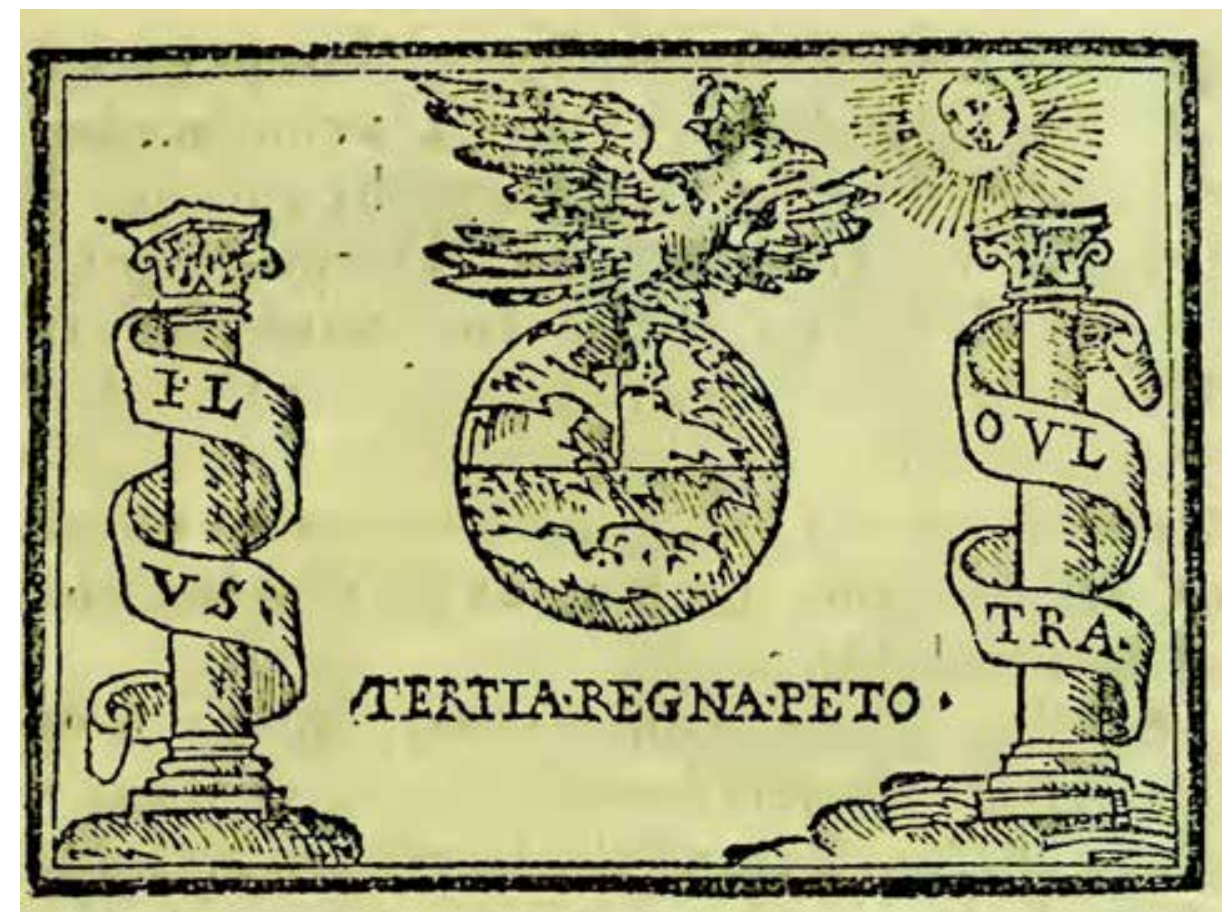

Illustration 10. The emblem of 34 "Non plus ultra. Tertia regna peto" (Covarrubias de Orozco 1610).

\section{Works Cited}

ARC (Archivo Regional del Cusco). Sección Notarial, Escribano Francisco Maldonado, Protocolo núm. 207, Con.to entre Joseph de Ochoa con Pedro de Vidauere $y$ otros (18.05.1702), f.176 r.-176 v.

Bernat Vistarini, Antonio, Cull, John T. Enciclopedia de emblemas españoles ilustrados. Madrid: Akal, 1999.

Bonet Correa, Antonio. Fiesta, poder y arquitectura. Aproximaciones al barroco español. Madrid: Akal. 1990.

Borja, Juan de. Empresas morales. Bruselas: Francisco Foppens, 1680.

Cadena, Carlos. Descripción de las Reales Exequias, que a la tierna memoria de Nuestro Augusto y Catolico Monarca, el Señor D. Carlos III, Rey de España y de las Indias, en los dias 9 y 10 de Julio de 1789. Guatemala, D. Ignacio Beteta, 1789.

Cornejo Bouroncle, Jorge. Derroteros de arte cuzqueño. Cuzco: Ediciones Inca, 1960. Covarrubias y Orozco, Sebastian de. Emblemas morales. Madrid, Luis Sanchez, 1610. 
Dean, Carolyn. Los cuerpos de los incas y el cuerpo de Cristo. El Corpus Christi en el Cuzco Colonial. Lima: Fondo Editorial de la Universidad Nacional Mayor de San Marcos, 2002 [1999].

Domínguez-Guerrero, María Luisa. "El poder del rey ausente: la proclamación de Felipe II en Cuzco en 1557." Anuario de Estudios Americanos 72.2 (2015): 606-29.

Esquivel y Navia, Diego de. Noticias cronológicas de la gran ciudad del Cuzco. Ed. Félix Denegri Luna, Lima: Fundación Augusto N. Wiese/ Banco Wiese Ltdo, 1980. García, José Uriel. La ciudad de los Incas. Cuzco: Lib. imp. H.G. Rozas, 1922.

García, Valdés, Celsa, Carmen. "Fiesta y poder en los virreinatos americanos." La Fiesta. Memoria del IV Encuentro Internacional sobre Barroco. Ed. N. Campos Vera, La Paz: Unión Latina, Embajada del Reino de los Países Bajos, 2007: 253-59. Gruzinski, Serge. La pensée métisse. Paris: Librairie Arthème Fayard, 1999.

Hidalgo Nuchera, Patricio. "La economía colonial." Historia de América. Ed. Juan B. Amores Carredano, Barcelona: Ariel, 2012: 451-528.

Horozco y Covarrubias, Juan de. Emblemas morales. Caragoça: Alonso Rodriguez, 1604.

Jouve Martín, José R. "The City of the Pheonix: Earthquakes, Royal Obsequies, end Urban Rivalries in Mid-Eighteenth Centuries." The Transatlantic Hispanic Baroque. Complex Identities in the Atlantic World. Eds. H. E. Braun, J. PrezMagallón, Farnham: Ashgate, 2014: 219-35.

Kantorowicz, Ernst. Los dos cuerpos del rey. Un estudio de teología política medieval. Trans. Susana Aikini Araluce. Madrid: Akal. 2012 [1957].

Kemen, Henry. Felipe V. El rey que reinó dos veces. Madrid: Editorial Temas de Hoy, 2000.

Kolb, Frank. Ideał późnoantycznego władcy. Trans. Anna Gierlińska, Poznań: Wydawnictwo Poznańskie 2008 [Herrscherideologie in der Spätantike, 2001].

Kubiak, Ewa. "Cultural metissage - a descriptive notion of hybrid phenomena on the peripheries of cultures." Art inquiry. Recherches sur les arts 16 (XXV) 2014: $147-166$.

Kubiak, Ewa. "La pintura de batalla en el Virreinato del Perú: Victorias de Carlos V en el Museo de la Casa de Moneda en Potosí (Bolivia)." Itinerarios. Revista de estudios lingüísticos, literarios históricos y antropológicos, 19 (2014): 75-94.

Kubiak, Ewa. Reinterpretacje. Percepcja i recepcja dzieł architektury na przykładzie świątýn jezuickich Ameryki Poludniowej okresu kolonialnego. Łódź: Wydawnictwo Uniwersyteckie, 2015.

Laplantine, François \& Nauss, Alexis. Le Métissage. De Arcimboldo à Zombi. Paris: Fayard 2001.

Lorea, Antonio de. David pecador, enpresas morales, politico cristianos. Madrid: Francisco Sanz, 1674.

Mariátegui Oliva, Ricardo. Pintura cuzqueña del siglo XVII. Los maravillosos lienzos del Corpus existentes en la iglesia de Santa Ana del Cuzco. Lima: Alma Mater, 1951. 
Mesa, José de \& Teresa Gisbert. Historia de la pintura cuzqueña. Lima: Fundación Augusto N. Wiese/ Banco Wiese Ltdo, 1982.

Mínguez, Víctor. "Los dos cuerpos de Carlos II", Libros de la Corte.es.Monográfico, 8, 4 (2016): 68-91.

Mínguez, Víctor. Los reyes distantes: imágenes de poder en el México virreinal. Castelló de la Plana: Diputación de Catsellón, 1995.

Mínguez, Víctor. Los reyes solares. Iconografía astral de la monarquía hispana. Castelló de la Plana: Universitat Jaume 1, 2001.

Mínguez, V., Rodríguez Moya, I., González Tornel, P., Chiva Beltrán, J. La fiesta barroca. Los virreinatos americanos (1560-1808). Castelló de la Plana-Las Palams: Publicacions de la Universitat Jaume I-Universidad de las Plamas de Gran Canaria, 2012.

Pérez-Mallaín Bueno, Pablo Emilio. Retrato de una ciudad en crisis. La sociedad limeña ante el movimiento sísmico de 1746. Lima: Pontificia Universidad Católica del Perú, Instituto Riva-Agüero, 2001.

Périssat, Karine. Lima fête ses rois (XVIe-XVIII siècles). Hispanité et américanité dans cérémonies royales. Paris: L'Harmattan, 2002.

Pietraszczyk-Sękowska, Joanna. Tradycje oporu w Andach. Mobilizacje indiańskochłopskie w Peru od XVI do XX wieku. Łódź: Wydawnictwo Uniwersytetu Łódzkiego, 2015.

Ramos Sosa, Rafael. Arte Festivo en Lima Virreinal: (Siglos XVI-XVII). Sevilla: Junta de Andalucía, Servicio de Publicaciones, 1992.

Rípodas Ardanaz, Daisy. "Versión de la monarquía de derecho divino en las celebraciobes Reales de la América borbónica." Revista de historia del derecho, 34 (2006): 241-67.

Roel Pineda, Virgilio. Historia social y económica de la colonia. Lima: Herrera Editores, 1999.

Ruiz de Pardo, Carmen. "La muerte privilegiada. Reales exequias en Lima y Cuzco. Época borbónica." Arte, poder e identidad en Iberoamérica. De los virreinatos a la construcción nacional. Ed. Inmaculada Rodríguez Moya, Castelló de la Plana: Publicacions de la Universitat Jaume I: 53-76.

Saavedro Fajardo, Diego de. Idea de un príncipe político christiano, representada en cien empresas. Monaco-Milan, 1640-1642.

Santander, José Antonio. La lealtad satisfecha, el jubilo ensalzado, y gratos reconocimientos de la fidelidad conque expresso su sentimiento la... Ciudad del Cuzco en las Exequias del S.D. Phelipe V. Lima: en la Imprenta que está en la Plazuela del pie del Cerro, 1748.

Vignolo, Paolo. "Más allá de las columnas de Hércules: un emblema de la Modernidad temprana." Historia cultural desde Colombia. Categorias y debates. Eds. M.S. Herring Torres, A.C. Pérez Benavides, Bogotá: Universidad Nacional de Colombia, 2012: 139-164. 
Villerias Roelas, José. Llanto de las estrellas al ocaso del Sol Anochecido en el Oriente. Solemnes exequias, que a la augusta memoria del Serenissimo, y potentísimo señor Don Luis I. Rey de España, celebró el Exemo. Sr. D. Juan de Acuña, Marqués de Casa Fuerte. Méxixo, Joseph Bernardo de Hogal, 1725.

Viñuales, Graciela María, El Espacio Urbano en el Cusco Colonial: uso y organización de las estructuras simbólicas. Lima: CEDODAL, 2004.

Ewa Kubiak - Ph.D., art historian and linguist; since 2002 affiliated with the Institute of Art History at Lodz University. She defended her doctoral dissertation at Cardinal Stefan Wyszyński University in Warsaw in 2002 and went on to work on Latin American colonial art. A recipient of the Lanckorońscy Foundation Fellowship of Brzezie (2004) and two fellowships of Foundation for Polish Science (conference fellowships in 2006 and 2008). Visiting Professor in Colombia (Universidad de los Andes, Bogota, 2015) and Peru (Universidad Nacional de Diego Quispe Tito, Cusco, 2018 and Universidad Nacional de San Antonio Abad en Cusco, 2020), she has authored numerous articles on colonial art, published in Polish, English and Spanish. She is particularly interested in the Andean territory of Viceroyalty of Peru. 